This is an electronic reprint of the original article. This reprint may differ from the original in pagination and typographic detail.

Author(s): Haapala, Taru

Title: The issue of the secret ballot in the Cambridge and Oxford Union Societies, c.1830-72: an extension of the nineteenth-century parliamentary culture of debate

Year: $\quad 2015$

Version:

Please cite the original version:

Haapala, T. (2015). The issue of the secret ballot in the Cambridge and Oxford Union Societies, c.1830-72: an extension of the nineteenth-century parliamentary culture of debate. Parliaments, Estates and Representation, 35(1), 66-83.

https://doi.org/10.1080/02606755.2014.976435

All material supplied via JYX is protected by copyright and other intellectual property rights, and duplication or sale of all or part of any of the repository collections is not permitted, except that material may be duplicated by you for your research use or educational purposes in electronic or print form. You must obtain permission for any other use. Electronic or print copies may not be offered, whether for sale or otherwise to anyone who is not an authorised user. 
The issue of the secret ballot in the Cambridge and Oxford Union Societies, c. 1830-72: An extension of the nineteenth-century parliamentary culture of debate

\section{TARU HAAPALA}

\section{SUMMARY}

In this article, debating societies are considered as an inherent part of the formation of a parliamentary culture in Britain. Despite the fact that the nineteenth-century Cambridge and Oxford Union Societies were considered to be 'training grounds' for statesmen, their debating practices have not been systematically studied in relation to national politics. This is largely due to the fact that the role of debate has remained understated in studies of parliamentary history, even though it is one of the fundamental political features in the Westminster system. Nineteenth-century parliamentary debate did not just occur for its own sake, rather it had a constitutional and political dimension that was related to procedure. This article focuses on the significance of the debate culture in nineteenth century British parliamentary politics. It shows that there was an interchange of ideas and concepts between the House of Commons and the Cambridge and Oxford Union Societies that enabled the extension of parliamentary procedure and terminology outside Parliament affecting the way that political activity was understood. It discusses the extension of parliamentary culture to Union Societies during the period between the 1830s and the 1870s. Its main argument is that 'debate' was a major political feature of parliamentary politics, which was reflected in the major discussions on reform, for example, in the case of secret voting. It is shown that the Union Societies did not merely follow the lead of the House of Commons, but that they actively contributed to the debate on reforms and, at the same time, to the formation of the debate culture of which the main principle to follow Walter Bagehot (1826-77), was that putting an issue on the political agenda was itself an admission of its controversial and unfixed character. 


\section{INTRODUCTION}

The British Parliament was originally constituted to grant supplies, rather than to make laws, and therefore its main purpose can be seen more as financial as opposed to legislative. ${ }^{1}$ Not only have its deliberations had an administrative character, of weighing pros and cons, but they have also been aimed at challenging the government, and this has made it different from the Continental and American legislatures. Even though deliberations are one of its most distinctive features, debate, or speaking pro et contra, has been rather understated in studies of British parliamentary politics. ${ }^{2}$

By the mid-nineteenth century, Westminster had assumed a central role in national politics and the debates in the House of Commons were part of a wider public culture. Within that parliamentary context, debating societies have also been rather sidelined as to their significance in the political culture. ${ }^{3}$ The most famous - the Union Societies at Cambridge and Oxford Universities—not only allowed students to practise their debating skills, but also gave them a chance to familiarise themselves with political topics and forms of debate before engaging in public careers. ${ }^{4}$ In particular, I argue that the Societies enabled their members to understand political activity in parliamentary terms, as a procedural performance that was realised in debates.

\footnotetext{
${ }^{1}$ See, for example, C. Ilbert, Legislative Methods and Forms, (Oxford, 1901), p. 209.

2 There are, however, a few studies that deal with the history of British political culture and parliamentary oratory in a general way. See, for example, M. Peltonen, Rhetoric, Politics and Popularity in PreRevolutionary England (Cambridge, 2013); C. Reid, Imprison'd Wranglers: The Rhetorical Culture of the House of Commons, 1760-1800 (Oxford, 2012); J. H. Grainger, Character and Style in English Politics (Cambridge, 1969).

${ }^{3}$ They have, however, been considered in connection with Victorian public life and oratory, in J. S. Meisel, Public Speech and the Culture of Public Life in the Age of Gladstone (New York, 2001). See also M. Bevis, The Art of Eloquence: Byron, Dickens, Tennyson, Joyce (Oxford, 2007); J. van Rijn, De eeuw van het debat: De ontwikkeling van het publieke debat in Nederland en Engeland, 1800-1920 (Amsterdam, 2010).

${ }^{4}$ J. F. Skipper, A Short History of the Cambridge University Union (Cambridge, 1878), p. 5. Nineteenthcentury Union Societies should not be conflated with student unions or other student organisations in the modern sense. The Unions' activities were extra-curricular and did not receive financial support from the universities.
} 
The parliamentary culture of the time cannot be fully understood without taking into account the series of reforms that began after the passing of the 1832 Reform Act. Although the effects of the Act on parliamentary representation remained relatively minor, its significance was that it ushered in a new political era which involved broad changes in the system of representation. ${ }^{5}$ At the same time a constitutional arrangement emerged that had profound implications for the way in which politics was conducted. By the mid-nineteenth century, 'parliamentary government' had become the dominant constitutional form and it affected the way politics was understood. ${ }^{6}$ In practice, the government had to enjoy the confidence of the majority of the House of Commons. ${ }^{7}$ Thus the importance of debate in the Commons grew, and a government's fate was tied to its ability to take leadership on issues that were publicly discussed. At the same time, the idea of debate became based on fairness in setting the political agenda (a topic rarely discussed in recent scholarship on nineteenth-century British politics), as had been provided for in earlier times by precedents of parliamentary procedure. To follow the procedure was to ensure the legitimacy of political issues.

This article will therefore argue that debate was a major political feature of parliamentary politics in the constitutional and political context of the mid-nineteenth century, and this was reflected in the key discussions on reform, for example, in the case of secret voting, as will be discussed. The aim is to show that the Union Societies were

\footnotetext{
5 C. Seymour, Electoral Reform in England and Wales: The Development and Operation of the Parliamentary Franchise, 1832-1885 (New Haven, 1915), p. 9.

6 A. Hawkins, “Parliamentary Government” and Victorian Political Parties, c. 1830-c. 1880', The English Historical Review, 104 (1989), p. 656.

7 The direct link created between the government and the parliament legitimised cabinet politics and made it increasingly difficult for the Crown to exercise its prerogative power (e.g. to appoint a government without the acceptance of the majority of the House of Commons). It has been suggested that the Crown's influence in parliamentary business was already declining well before 1832. See, for example, A. S. Foord, 'The Waning of “The Influence of the Crown”', The English Historical Review, 62 (1947), pp. 486-88. However, it has also been pointed out that as late as November 1834 a British monarch was allowed to use royal prerogative to remove a government that enjoyed the confidence of the House of Commons majority. For an elaboration, see A. Hawkins, The Forgotten Prime Minister: The $14^{\text {th }}$ Earl of Derby, 2 vols (Oxford, 2007, 2010), vol. 1: Ascent: 1799-1851 (2007), p. 152.
} 
not mere debating societies that imitated the constitutional model through their adoption of many parliamentary features, but that they themselves played an active role in shaping the political culture of their time by participating in the political discourse and by practising parliamentary-styled debate. In particular, this article discusses the relevance of the debate topics presented in the Union Societies within the broader framework of nineteenth-century British parliamentary culture.

The topics discussed in the Cambridge and Oxford Unions’ meetings have not been systematically studied in relation to national politics, even though there are a number of important political issues recorded in their minute books that reflect the period. The lack of research on the debate practices of the Union Societies is also somewhat surprising given their later reputation as the 'training grounds' of many great statesmen. ${ }^{8}$ I maintain that the Union Societies of Cambridge and Oxford are parts of British parliamentary history that have been unduly neglected, especially when one considers how they express the political ideas of debate. The Unions' minute books provide significant information about the forms and practices of their debates as well as the major topics of the political discourse. They are as indispensable as are the Hansard and other parliamentary records in providing information about the idea of debate and for seeing how the practices at Westminster had the effect of introducing parliamentary culture to the public at large.

My analysis of the Unions' debates ${ }^{9}$ offers an interpretation of what kind of political activity ensued in the political landscape changed by the 1832 Reform Act. Although there are many studies about the institutional changes of reforms, no serious attempts have been made to analyse their effects on the parliamentary culture in terms

\footnotetext{
${ }^{8}$ P. Cradock, Recollections of the Cambridge Union, 1815-1939 (Cambridge, 1953), p. 1; F. Gribble, 'The Oxford Union', Edinburgh Review, 239 (1924), p. 46. See also J. N. Temple and E. P. Dunn, 'British Debating is Parliamentary', The Quarterly Journal of Speech, 34 (1948), p. 50.

9 T. Haapala, “That in the opinion of this House': The Parliamentary Culture of Debate in the Nineteenth-Century Cambridge and Oxford Union Societies’ (University of Jyväskylä, PhD thesis, 2012).
} 
of publicity and political deliberation. ${ }^{10}$ In order to fill that gap, this paper presents an interpretation of how the reforms affected political activity and reset the political agenda due to the new requirements for debate and public deliberation.

I will begin by taking a closer look at the constitutional and political framework that guided politics at least between the two major Reform Acts in 1832 and 1867. While this article does not pretend to be an exhaustive account of the politics of reform of the period, the aim is to shed more light on the political cultural aspects and effects of the reforms in this period of British parliamentary history. I will then move on to discuss how the Union Societies can be considered an extension of the parliamentary culture that had been formed. I will focus on the existence of bribery and intimidation that remained prominent features of the British representational system. A conspicuous effect of the 1832 Reform Act was that it actually increased the amount of electoral corruption as the old nomination system was abolished. The corrupt practices in elections were common and they affected the independence of voters. ${ }^{11}$ By reflecting on these aspects related to the secret ballot debate I will show how the Unions were following and contributing to some of the key political topics of their time.

THE CHANGED LANDSCAPE OF POLITICAL ACTIVITY IN NINETEENTHCENTURY PARLIAMENTARY CULTURE

The formation of the Union Societies (Cambridge in 1815 and Oxford in 1823) coincided with the period after the Napoleonic wars when unrest throughout the country made it requisite for government to get in touch with the masses of people that largely remained disfranchised. In the first Reform Bill debates, the Grey government argued

\footnotetext{
${ }^{10}$ Some interesting insights regarding the language of reform have been provided in the volume by A. Burns and J. Innes (eds.) Rethinking the Age of Reform: Britain 1780-1850 (Cambridge, 2003). In the field of historical institutionalism, parliamentary reforms have been treated from the perspective of constitutional politics in A. Kelso, Parliamentary Reform at Westminster (Manchester, 2009).

${ }^{11}$ Seymour, Electoral Reform, p. 193.
} 
for disfranchisement of certain boroughs in order to eliminate electoral corruption and open up these constituencies to electoral competition. The Tories objected to the abolition of the so-called 'nomination boroughs' with the argument that they had been 'nurseries for nascent statesmen'. ${ }^{12}$ In their view, the predictability of obtaining a parliamentary seat guaranteed continuity even with new generations of politicians. But after the passing of the 1832 Reform Act the competition between political parties over the seats grew. In this new political landscape it was crucial to practise public deliberation and parliamentary-styled debate. Although the majority of the Unions' members did not pursue parliamentary careers, those who aspired to become parliamentarians greatly benefited from the Societies' debates. ${ }^{13}$ Such prominent statesmen as Thomas Babington Macaulay (1800-59) and Winthrop Mackworth Praed (1802-39) had contributed to the pre-Reform Bill debates of the Cambridge Union Society in the 1820s. In the late nineteenth century, reportedly nearly a fifth of the members of the House of Commons and 'a considerable number' of the House of Lords had been members of the Oxford Union. ${ }^{14}$ This strongly suggests that the Unions were not merely debating societies, but played an active and decisive role in shaping the political culture of their time.

In post-1832 reform Britain, the role of Westminster was central to national politics and its debates became an integral part of the surrounding public culture. This change was certainly seen in that parliamentary questions 'came to be more and more a method of insisting on what was known as 'reform', between 1815

\footnotetext{
${ }^{12}$ Seymour, Electoral Reform, p. 53. In the early 1860s Bagehot still defended this system in the context of Gladstone's son's candidature.

${ }^{13}$ It should be noted that some members were reported to have considered the Union as one of their 'schools', e.g. H. H. Asquith, Prime Minister between 1908 and 1916. See Gribble, 'The Oxford Union', p. 46.

${ }^{14}$ J. B. Harris-Burland, 'The Oxford and Cambridge Union Societies, I. Oxford', Strand Magazine, 7 (1894), p. 502.
} 
and 1832. ${ }^{15}$ By the mid-nineteenth century, a parliamentarian's reputation was dependent on his oratorical skills, and debating societies became instrumental in providing training. ${ }^{16}$ Ultimately, it accentuated the idea of the British Parliament as being an assembly of which the primary function was not to legislate, but to debate according to certain rules and principles. ${ }^{17}$ In 1867 Walter Bagehot described the preceding thirty years of cabinet government as a period of controversy and debate. Parliament had become a legislative assembly that was 'the great scene of debate, the great engine of popular instruction and political controversy'. ${ }^{18}$ He observed that the House of Commons had become the 'true sovereign' that governed the country in the form of a public meeting. ${ }^{19}$ This meant that the control of the financial and administrative functions became the joint responsibility of the cabinet, which comprised members of Parliament, and individual members, who served in various parliamentary committees. ${ }^{20}$ Nineteenth-century parliamentary debate did not just occur for its own sake, but it had a constitutional and political dimension that was related to procedure. Since then many accounts of British parliamentary political culture consider debate in procedural terms. Ernest Barker, for example, regards parliamentary democracy as a 'process of discussion, or a method of collecting views and taking decisions on the views so collected' and emphasises the role of parliamentary rules of procedure for this purpose. $^{21}$

\footnotetext{
${ }^{15}$ P. Howarth, Questions in the House: The History of a Unique British Institution (London, 1956), pp. $74-5$.

${ }^{16}$ Grainger, Character and Style, p. 15.

${ }^{17}$ J. Redlich, The Procedure of the House of Commons: A Study of its History and Present Form, 2 vols (London, 1908). Translated from German by A. Ernest Steinthal, with an introduction by Sir Courtenay Ilbert, Clerk of the House of Commons, vol. 2, p. 215.

${ }^{18}$ W. Bagehot, The English Constitution, P. Smith (ed.), Cambridge Texts in the History of Political Thought (Cambridge, 2001), p. 14.

${ }^{19}$ Bagehot, The English Constitution, pp. 98-9.

${ }^{20}$ On the difference between British parliamentary committees and the specialist-based US committees, see G. Campion, 'Parliamentary Procedure: Old and New', in G. Campion et al., Parliament: A Survey (London, 1853), pp. 158-9.

${ }^{21}$ E. Barker, Reflections on Government (Oxford, 1942), p. 210.
} 
Parliamentary debate became so highly valued as a foundation of representative government that, in practice, it created obstacles for the government's administration and the functioning of the House of Commons. Since the passing of the 1832 Reform Act, the number of petitions received at Westminster had grown sharply, increasing the amount of business in the House even further. ${ }^{22}$ During the period between 1828 and 1832 the total number of petitions was 23,283, and by 1838-42 the number was 70,072. The peak was reached immediately after the Second Reform Act between 1868 and 1872, with a total of $101,573{ }^{23}$ The great amount of petitions is reflective of the way Parliament was perceived at the time. It was the key political arena in which matters of national importance were debated.

Constitutionally, debate became a central element of the legitimisation of parliamentary political activity during the period. Thomas Babington Macaulay, for instance, described parliamentary government as 'government by speaking', ${ }^{24}$ and Bagehot equally spoke of 'government by discussion'. ${ }^{25}$ In Physics and Politics (1872), Bagehot provides an interesting account of the period between the two parliamentary reforms. He discusses free political discussion and relates it to the growth of tolerance and the development of civilisations. In his view, a 'government by discussion' is formed when there is a 'change from the age of status to the age of choice' ${ }^{26}$ His main assertion is that the idea of a break with custom is central:

\footnotetext{
22 The practice of delegating petitions to a standing committee began only around 1860 .

${ }^{23}$ Quoted in T. A. Jenkins, Parliament, Party and Politics in Victorian Britain (Manchester, 1996), p. 16.

24 T. B. Macaulay, 'William Pitt. (January 1859.)', in The Miscellaneous writings and speeches of Lord Macaulay, Contributions To The Encyclopaedia Britannica And Miscellaneous Poems, Inscriptions, Etc. by Thomas Babington Macaulay, 4 vols (London, 1889), III, $<$ http://www.gutenberg.org/dirs/2/1/6/2169/2169.txt> [accessed 14 February 2014].

${ }^{25}$ W. Bagehot, 'Physics and Politics. (1872.)', in The Works and Life of Walter Bagehot, edited by Mrs Russell Barrington, 9 vols (London, 1915), VIII, <http://oll.libertyfund.org/title/2166/200866> [accessed 14 February 2014].

${ }^{26}$ Bagehot, Physics and Politics, 'No. V.: The Age of Discussion'.
} 
[A] government by discussion, if it can be borne, at once breaks down the yoke of fixed custom. ... [T] with the object of being guided by that discussion, is a clear admission that that subject is in no degree settled by established rule, and that men are free to choose in it. $^{27}$

Bagehot argued that the development of a highly civilised nation, such as Britain, is dependent on its ability to discuss political questions 'with freedom'. Viewed from this angle, the Union Societies' debating practices show that they had adopted similar cultural ideas, and thus were very much part of the 'age of discussion'.

By the 1850s, the Union Societies had grown in membership and their weekly debates were attracting outside attention. At Oxford, it was common to invite visitors to attend the debates. A number of newspaper announcements of the issues debated were published accompanied by the voting results. ${ }^{28}$ It was not uncommon for either Union Society to discuss motions on whether a given government or government policy enjoyed the 'confidence of the House'. Both Unions had started to formulate their motions to express resolutions of a 'House': 'That this House wishes to express its full confidence in the present ministry'. ${ }^{29}$ By debating on whether or not the Union should give its confidence and support to a government, their members were trying to persuade their audiences of whether or not they should make a resolution for or against the party that held the majority in the House of Commons. Debates on party political alliances were also common. 'Parliamentary government' was able to function in part

\footnotetext{
${ }^{27}$ Bagehot, Physics and Politics, 'No. V.: The Age of Discussion'.

${ }^{28}$ Both Union Societies banned publication of their debates. Despite the restriction some members of the Societies informed newspapers about their meetings. Once the Unions had established themselves in academic life, the rules concerning visitors became less strict. The Oxford Union started to publish its debate proceedings in 1856. At Cambridge members of the Union were given the right to publish the subject of debate, the result and the names of speakers in 1868.

${ }^{29}$ Slipper, motion presented in the Oxford Union, 3 March 1864, Oxford Union Minute Book, vol. IX.
} 
due to the authority and reputation that was accorded to well-established statesmen and also due to the statesmen's skills in forming party alliances. Mid-nineteenth-century British party politics was very flexible because the political parties were not yet organised in the modern sense. Prior to the 1870 s the British party system did not function according to the modern 'two-party alignment'. ${ }^{30}$ Party alliances were forged and abandoned largely according to the political expediencies of the moment. Due to the constitutional setting, the authority of the executive rested on the shifting opinions of the House of Commons; thus, a 'mediation' of interests inside the House was the aim of any politically farsighted government. ${ }^{31}$ As an example, in 1832, the Oxford Union discussed a motion concerning the Conservative party's chances of forming a government: 'That there being at present no hope of the establishment of any permanent Tory Ministry, the Conservative party will best consult the interest of the country by firmly supporting the present Government' ${ }^{32}$ An amendment to this motion was also proposed: 'That it is desirable that the Tory and Whig parties should form a coalition against their common enemies'. ${ }^{33}$ Here the political advantages of forming a coalition between the Tories and the Whigs seem to have been more accentuated than adherence to party principles. The example illustrates that the Union debates were not conducted merely on an academic or theoretical level, but there were clear political dimensions of argumentation. Motions were produced in specific political contexts and should not be seen as encapsulating some pre-defined principles of their proposers which were used to defend a viewpoint merely for the sake of argument.

The Unions managed to attract a following in the two old English universities, where no education in political matters or on the practice of debate were

\footnotetext{
${ }^{30}$ Hawkins, “"Parliamentary Government”, p. 643.

${ }^{31}$ Hawkins, “"Parliamentary Government”', pp. 650-651.

32 Ward, motion presented in the Oxford Union, 8 November 1832, Oxford Union Minute Book, vol. II.

33 De Visme, amendment presented in the Oxford Union, 8 November 1832, Oxford Union Minute Book, vol. II.
} 
provided. ${ }^{34}$ The formulations of debate topics reveal how the members conceived of political action on the basis of their knowledge of parliamentary politics. The results of the debates were contingent and depended largely on the attendance of the members. The outcomes of debates for and against, e.g. on the government ministries, were considered of importance because they potentially affected and reflected opinionbuilding inside the universities.

\section{THE DEBATE ON THE SECRET BALLOT IN THE UNION SOCIETIES}

The Union Societies were founded in the early nineteenth century for the specific purpose of promoting debate. The Cambridge Union, established at the end of the Napoleonic wars in 1815, was partly modelled after the smaller, private debating clubs that had existed in the old English universities. ${ }^{35}$ The Union was formed when three such clubs were fused together. Debates on current political issues were frequent in the Union, and resulted in a temporary debating ban from 1817 to 1821 . Two years later the Oxford Union Debating Society was founded. The Society was reconstituted in 1825 as the Oxford Union Society. After obtaining rooms for debates and a library, one of the Society’s first book purchases was Hansard from $1800 .^{36}$

At Westminster, the secret ballot was an issue that was frequently raised on the parliamentary agenda between the 1830s and the $1860 \mathrm{~s},{ }^{37}$ that is, during the two

\footnotetext{
${ }^{34}$ This was the case at least until the 1850s, when the History and Moral Sciences Triposes, which included politics and political philosophy, were established. See S. Collini, D. Winch and J. Burrow, That Noble Science of Politics. A Study in Nineteenth-Century Intellectual History (Cambridge, 1983), pp. 344-7.

${ }^{35}$ In fact, one of the Union's founders, Charles Fox Townshend (1795-1817), had been involved in the formation of yet another famous debating club, the Eton Society, a few years earlier in 1811. See G. Martin, 'Ch. 5: The Early Years of the Cambridge Union', in G. Martin, The Cambridge Union and Ireland, 1815-1914 (Edinburgh, 2000),

$<$ http://www.gedmartin.net/index.php?option=com_content\&task=view\&id=133> [accessed 14 February 2014].

36 (unknown author), History of the Oxford Union Society (Oxford, 1908), p. 4.

${ }^{37}$ J. H. Park, 'England's Controversy over the Secret Ballot', Political Science Quarterly, 46 (1931), pp. 51-86.
} 
parliamentary reforms. Until the 1830s, the secret ballot was mostly propagated by the Philosophical Radicals, who had a considerable number of extra-parliamentary followers. The Radicals considered the adoption of the secret voting method a significant step forward for democracy in England. ${ }^{38}$ Despite the abolition of the rotten boroughs, the Reform Act of 1832 had not diminished corruption as intended, but rather exacerbated the problems. In fact, with the new distribution of seats and independence of voters from the old patronage system, electoral bribery increased significantly during the following two decades. ${ }^{39}$ Candidates were often required to pay the voters. In this system the parliamentarians_-Liberals and Conservatives alike—could buy their seats from voters and that way ensure their electoral victory. The voters, on the other side, had an additional source of income. Forms of indirect bribery, such as money lending, were also practised. In larger constituencies, intimidation was involved in every election. ${ }^{40}$ The Radicals and more liberal Whigs started to find ways to protect voters from bribery and intimidation. The reformers advocated for the secret voting system outside Parliament in order to find wider support for their cause. This political discussion was reflected in the Cambridge Union in the 1830s and the early 1840s. For example, the adoption of the secret ballot was debated in 1833: 'Whether vote by Ballot in the election of Members of the Commons House of Parliament is beneficial? ${ }^{41}$ There were only 3 votes for the motion and 26 against. Some years later the same topic was discussed more substantially in the motion: 'Is the introduction of the ballot advisable in Parliamentary elections? ${ }^{42}$ The debate was adjourned until next meeting, which shows

\footnotetext{
${ }^{38}$ H. Buchstein, Öffentliche und geheime Stimmabgabe. Eine wahlrechtshistorische und ideengeschichtliche Studie (Baden-Baden, 2000), p. 328.

${ }^{39}$ Seymour, Electoral Reform, p. 174.

40 Seymour, Electoral Reform, p. 181.

${ }^{41}$ Burke, motion presented in the Cambridge Union, 7 May 1833, Cambridge Union Society Minute Book, vol. 8.

42 Christie, motion presented in the Cambridge Union, 31 January 1837, Cambridge Union Society Minute Book, vol. 9.
} 
that it was not considered an insignificant issue, although the majority was eventually against it. The secret ballot was also on the Oxford Union's debate agenda in between 1833 and 1845. In 1838, for example, the question was formulated 'That votes for Members of Parliament ought to be taken by ballot'. ${ }^{43}$ The debate continued a week later, when there were 7 in favour and 67 against the motion.

In 1830, Daniel O’Connell, the famous Irish MP, had proposed a motion regarding secret voting in the House of Commons. ${ }^{44}$ O’Connell was one of the first parliamentarians who had an extra-parliamentary following, and he was notorious for his involvement in London radical circles. In March, he had chaired the launch of the Metropolitan Political Union and spoke at a mass meeting in favour of the secret ballot, as well as shorter parliaments and universal suffrage. ${ }^{45}$ Besides O’Connell there were also other advocates of the ballot in the House of Commons that most likely inspired Union debates. One of the associations that promoted the secret ballot was the 'Birmingham Political Union'. Thomas Attwood and other radicals established this association in 1830 for the purpose of promoting parliamentary reform among the lower and middle classes. In reference to that, the Oxford Union debated in 1831: 'That the recognition of the Birmingham Political Union by Lord Althorp and Lord John Russell was highly imprudent and unconstitutional' ${ }^{46}$ The motion shows that the Oxford Union was debating the legality of the Political Union. The rhetoric of unconstitutionality and suspicions against extra-parliamentary political associations for their revolutionary character was common at the time. In the 1830s, a number of magazines, among them

\footnotetext{
${ }^{43}$ Moncreiff, motion presented in the Oxford Union, 31 May 1838, Oxford Union Society Minute Book, vol. IV.

${ }^{44}$ O’Connell, speech to the House of Commons, 28 May 1830, Parliamentary Debates, Commons, second series, vol. 24, col. 1204.

45 'O'Connell, Daniel (1775-1847)', in D.R Fisher (ed.), The History of Parliament: The House of Commons 1820-1832 (Cambridge, 2009), <http://www.historyofparliamentonline.org/volume/18201832/member/oconnell-daniel-1775-1847> [accessed 14 February 2014].

${ }^{46}$ Doyle, motion presented in the Oxford Union, 24 November 1831, Oxford Union Society Minute Book, vol. II.
} 
the Quarterly Review and Fraser's, opposed the ballot, arguing it would destroy the monarchy and replace it with a republic. ${ }^{47}$ In other words, the ballot was seen as going a step too far in terms of the constitutional arrangement.

Constitutional questions in the Unions were most commonly formulated in terms of national benefit. This was also the case in Cambridge: 'Would a Republican form of government be better adapted to the forwarding of the prosperity of England than that which she now enjoys or labours under? ${ }^{48}$ The majority of members who spoke in this debate were against the proposition. Concern about the secret ballot's possible negative effects on the country was shown in another debate: 'Would the introduction of vote by ballot in parliamentary elections be productive of good to, or would it entail evil on, the country? ${ }^{49}$ The majority of the Unions' members debating and voting on the issue remained adamantly opposed to the secret ballot.

The Philosophical Radicals argued that parliamentary reform would not be complete without the secret ballot. In 1833, George Grote, ${ }^{50}$ who led the proponents of the ballot in the Commons, proposed 'That it is expedient that the votes at elections for Members of Parliament be taken by way of Ballot' ${ }^{51}$ The majority of the Conservative opposition was against the motion. The Conservatives claimed that the adoption of secret ballot would weaken and erode the powers of the aristocracy and render the House of Commons too susceptible to the dangers of democracy, seen as demagoguery or 'mob rule'. Despite defeat, Grote and his supporters kept returning the issue to the

\footnotetext{
${ }^{47}$ Park, 'England's Controversy', p. 63.

${ }^{48}$ Warburton, motion presented in the Cambridge Union, 21 February 1832, Cambridge Union Society Minute Book, vol. 7.

${ }^{49}$ Watson, motion presented in the Cambridge Union, 11 November 1834, Cambridge Union Society Minute Book, vol. 8.

${ }^{50}$ Grote (1794-1871) was a close associate of John Stuart Mill. He had been elected MP for the City of London for the reformed Parliament (1832-41). Later he became known as a remarkable historian of ancient Greece and Rome.

${ }^{51}$ Grote, speech to the House of Commons, 25 April 1833, Parliamentary Debates, Commons, third series, vol. 17, col. 629 .
} 
House in the form of petitions from 1835 to $1839 .{ }^{52}$ They organised the so-called Ballot Union, which also attracted a considerable amount of adherents outside Parliament. However, the proponents of the secret ballot remained in the minority in the Commons, as the conservative Whigs and Tories were still firmly against the motion. Discouraged, Grote left his parliamentary seat after the 1841 elections.

After the 1830s the secret ballot continued to be a controversial issue around which a considerable amount of national attention and agitation was stirred up as it became connected with nationalistic rhetoric. It was sometimes referred to as the 'American ballot'. The American experience with the secret ballot was used as an argument by advocates and the critics alike. ${ }^{53}$ Those who opposed adoption of the ballot argued that secret voting was not consistent with the national tradition. The issue was discussed in various magazines, pamphlets and extra-parliamentary organisations.

By the early 1840s the Chartist movement took a more prominent role in the reform agitation and organising of mass meetings. But, for political reasons, they did not endorse the secret ballot. ${ }^{54}$ The Chartists considered that adopting the ballot would result more in a loss of the indirect political influence working men had in elections. ${ }^{55}$ The extra-parliamentary movement promoting the issue of secret voting effectually disappeared. The ballot was, however, kept on the House of Commons' agenda. It had a long-term proponent, Francis Henry Berkeley (1794-1870), a Liberal MP elected from Bristol in 1837. Between 1848 and 1867 he regularly moved the adoption of the secret ballot in the Commons and became known as something of a political opportunist. He first proposed a motion on the subject in August 1848, while the topic was also debated in the Cambridge Union on 15 November when a member

\footnotetext{
${ }^{52}$ Park, 'England's Controversy', p. 58.

${ }^{53}$ H. H. Asquith, 'The Ballot in England', Political Science Quarterly, 3 (1888), p. 654.

${ }^{54}$ Buchstein, Öffentliche und geheime, pp. 335-6.

${ }^{55}$ This idea was connected with the voting practice that compelled electoral candidates to use bribes in order to get elected.
} 
moved: 'That this House looks with disapprobation upon all attempts to introduce voting by ballot at the election of Members of Parliament'. ${ }^{56}$ The vote showed that secret voting was not widely endorsed among the Union members at the time as the issue lost by 45 for to 5 against. One of the debaters against the adoption of secret ballot was William Vernon Harcourt, ${ }^{57}$ who also took part in the parliamentary debates on the issue in the early 1870s. It seems that Harcourt's opposition to the ballot had remained constant since his Union days. In March 1851, he also took part in another Union debate on the same topic: 'That Vote by ballot would fail to accomplish its intended object; and would be productive of great injury to the National Character'. ${ }^{58}$ This time the proposal was moved some months earlier than Berkeley's annual motion in the Commons, which was delivered on 8 July. In the Union debate, Harcourt again took the side that opposed the secret ballot. And, on this instance, the motion was formulated so as to relate the ballot to the national character, which language was prominent in the political vocabulary of the educated classes during the period. Contemporaries judged political action on the basis of a person's (or a nation's) ascribed qualities. For political ends, national 'character' was juxtaposed to foreign traditions and values. ${ }^{59}$

In 1852 a renewed interest in the secret ballot was taken by the free-trade promoting 'Cobdenites'. They started to advocate it through, for example, the Ballot Society that Cobden had founded that year. But the activities of the Society remained rather marginal and did not manage to attract the same amount of followers as the

\footnotetext{
${ }^{56}$ Piffard, motion presented in the Cambridge Union, 15 November 1848, Cambridge Union Society Minute Book, vol. 14.

${ }^{57}$ Harcourt (1827-1904) was a member of the Cambridge Union and elected president in 1849. His political career began in 1868 when he entered Parliament as Liberal member for the borough of Oxford. He was appointed the first Whewell Professor of International Law at Cambridge University in 1869. In the late 1880s and the 1890s, he served in Gladstone government.

${ }^{58}$ P. A. Smith, motion presented in the Cambridge Union, 11 March 1851, Cambridge Union Society Minute Book, vol. 15.

${ }^{59}$ S. Collini, Public Moralists: Political Thought and Intellectual Life in Britain (Oxford, 1991), pp. 1067.
} 
movement in the $1830 \mathrm{~s} .{ }^{60}$ However, they managed to incorporate the question of the ballot in the Commons' debate on parliamentary reform. ${ }^{61} \mathrm{~A}$ few days later, on 30 March 1852, Berkeley made his own proposal for the adoption of the secret vote. Both Union Societies followed suit and debated on the topic in April $1853 .{ }^{62}$ Opposition to secret voting remained strong in the Cambridge Union. When it was moved 'That this House is of the opinion, that the introduction of Vote by Ballot is desirable, as a means of securing the purity of elections', ${ }^{63}$ the outcome of this debate was only 7 members in favour and 40 against. A similar attitude seems to have been present at Oxford as well. When it was moved 'That vote by ballot is eminently calculated to produce a beneficial effect on the present state of the country, and ought to be adopted', ${ }^{64}$ majority of those present at the debate voted against the proposition (45, versus 15 votes for the motion).

By the 1850s constitutional rhetoric stopped being the focus of debate on secret voting. Instead, a rhetoric of 'un-Englishness' became dominant in the anti-ballot discussions. In 1856, The Times had declared the secret ballot 'impossible' in England: 'The question has been well argued out, and, in spite of an appearance of mathematical precision in the manner of stating and supporting the Ballot, the feelings, as well as the reason of the nation, are all on the side of public voting' ${ }^{65}$ The general mood in the country, even among Radicals and Liberals, was that secret voting was objectionable on

\footnotetext{
${ }^{60}$ Buchstein, Öffentliche und geheime, p. 337.

${ }^{61}$ In 1852, Joseph Hume, a Radical MP and follower of Cobden, moved a parliamentary reform bill in the House of Commons.

62 Two months previously, Lord Russell had formed a government after the collapse of the Derby ministry. Early in the 1853 session it still looked like the newly elected prime minister would introduce a reform bill in the House of Commons, but it was postponed.

${ }^{63}$ E. Dicey, motion presented in the Cambridge Union, 12 April 1853, Cambridge Union Society Minute Book, vol. 16.

${ }^{64}$ Harvey, motion presented in the Oxford Union, 10 April 1845, Oxford Union Society Minute Book, vol. VI.

${ }^{65}$ In an editorial of The Times, Wednesday 10 December 1856, p. 8.
} 
the grounds of national tradition and values. ${ }^{66}$ A major claim of the time was that the ballot represented concealment, which went against English values.

The ballot would have signalled a radical change in the election procedure because the current voting practice was based on public deliberation. Open public support for electoral candidates was considered valuable in the constitutional context. It was construed as protection against a decline of debate itself. John Stuart Mill, for instance, who radically changed his mind on the secret voting, ${ }^{67}$ went so far as to compare the position of the voter to that of the parliamentarian. ${ }^{68}$ In his view, the growth of bribery was an indication of the independence of voting: it showed that landlords did not hold the same sway over the will of the electorate as they used to. ${ }^{69}$ Mill associated open voting with parliamentary debate, even though public deliberation related to voting in elections essentially differed from the debates in Westminster. In elections, debate was a rather secondary performance, as the main purpose of open voting was the public endorsement of a candidate, whereas in Parliament debate was considered a primary function with an emphasis on deliberative rhetoric, the persuading of the opposite side.

Opposition to the secret voting was also firmly present when the Oxford Union next debated in 1858 the motion 'That it is just and expedient that vote by Ballot

\footnotetext{
${ }^{66}$ B. L. Kinzer, 'The Un-Englishness of the Secret Ballot', Albion: A Quarterly Journal Concerned with British Studies, 10 (1978), p. 248.

${ }^{67}$ Previously Mill had taken the stand of supporting the adoption of ballot. But in 1859, he wrote in Thoughts on Parliamentary Reform that the ballot enabled a voter to advocate his own selfish interests and, therefore, it should not replace the open voting that made him 'defer to the opinions and wishes of others'. In other words, Mill accentuated the duties of voting and representation, instead of the political freedom of the voter.

${ }^{68}$ J. S. Mill, Considerations on Representative Government (1861), 'Chapter X: Of the Mode of Voting', in The Collected Works of John Stuart Mill, Volume XIX - Essays on Politics and Society Part II, J.M. Robson (ed.), Introduction by A. Brady (Toronto and London, 1977), $<$ http://oll.libertyfund.org/title/234/16590> [accessed 14 February 2014].

${ }^{69}$ Mill, Considerations on Representative Government, 'Chapter X: Of the Mode of Voting'.
} 
should be employed in the Election of Members of Parliament'. ${ }^{70}$ This time there were 12 for and 35 against. The Cambridge Union debated the secret ballot in November: 'That this House would regard with satisfaction the introduction of the system of voting by ballot at the election of Members of Parliament'. ${ }^{71}$ There were only 9 votes for the motion and 65 against. In the same year a parliamentary reform bill proposed by Lord Derby and Disraeli had been debated in the Commons. Berkeley's motion for the adoption of the ballot was discussed on 8 June, two days before the second reading of the parliamentary reform bill. The government collapsed after the bill failed to get the support of the majority in the Commons.

The next time secret voting was debated in the Cambridge Union was in 1861. This was after the secret ballot had been discussed in connection with the Representation of the People Bill, and after Berkeley’s separate bill to adopt the ballot had gained the support of a peer, Lord Teynham, who moved the same issue in the House of Lords in 1860. At Cambridge, the formulation of the motion was on 7 May: 'That it is the opinion of this House that, for the prevention of corrupt practices in elections, the ballot is desirable'. ${ }^{72}$ The motion was defeated by a clear margin: 9 for and 36 against.

The parliamentary debates were also reflected at Oxford in 1863. Berkeley's ballot motion had managed to get to the second reading stage in February, but was defeated. He put forward another motion in June. Later that year at Oxford, the topic was formulated: 'That it is expedient that the votes at parliamentary elections be

\footnotetext{
${ }^{70}$ A. V. Dicey, motion presented in the Oxford Union, 25 October 1858, Oxford Union Society Minute Book, vol. VIII. Dicey (1835-1922) became later known as a major constitutional theorist who promoted parliamentary supremacy. Another speaker in favour of ballot was T. H. Green (1836-82), who became a political philosopher and took active part in the local politics of Oxford.

${ }^{71}$ J. J. Cowell, motion presented in the Cambridge Union, 30 November 1858, Cambridge Union Society Minute Book, vol. 17.

${ }^{72}$ W. Savory, motion presented in the Cambridge Union, 7 May 1861, Cambridge Union Society Minute Book, vol. 17.
} 
taken by way of ballot'. ${ }^{73}$ The majority were against the motion: there were 10 in favour and 23 in opposition. For the Cambridge Union it took a couple more years to take up the issue again. In 1865 a motion was proposed: 'That in the opinion of this House, the adoption of the ballot in parliamentary elections would be unadvisable'. ${ }^{74}$ There was no surprise in the division of votes: the majority was in favour of the motion with 28 votes, there being 15 in opposition.

Although some working-class men gained suffrage in 1867, the open voting meant that many of them were unable to participate in practice. The viva voce voting method had effectively excluded workers, since under it they often had difficulties in participating in the lengthy process. Yet the bigger problem still was the corruption and inefficiency of the voting system, which became so conspicuous in the general elections of 1868 that Parliament set up a select committee to look into the adoption of the ballot.

In 1870 the Oxford Union debated a proposition 'That vote by ballot violates the true principles of political freedom and ought to form no part of the programme of the Liberal government'. ${ }^{75}$ An amendment was proposed 'That the use of the Ballot at Parliamentary Elections is absolutely necessary as a check against Bribery \& Intimidation'. ${ }^{76}$ The majority was for the amendment (11, there being 7 against). Their debate on the question was conducted at precisely the time a parliamentary select committee began 'to inquire into the present modes of conducting Parliamentary and Municipal Elections, in order to provide further guarantees for their tranquillity, purity,

\footnotetext{
73 Strachan-Davidson, motion presented in the Oxford Union, 12 November 1863, Oxford Union Society Minute Book, vol. IX.

${ }^{74}$ H. L. Anderton, motion presented in the Cambridge Union, 9 May 1865, Cambridge Union Society Minute Book, vol. IX.

${ }^{75}$ C. R. MacChymont, motion presented in the Oxford Union, 17 February 1870, Oxford Union Society Minute Book, vol. X.

76 Robertson, amendment presented in the Oxford Union, 17 February 1870, Oxford Union Society Minute Book, vol. X.
} 
and freedom'. ${ }^{77}$ The Cambridge Union also, just a month before the motion to form the select committee was put forward in the Commons, debated 'That this House would view with dissatisfaction the use of the Ballot at Parliamentary Elections' ${ }^{78}$ At Cambridge, the majority were for the motion, there being 55 in favour and 29 against it, showing that the majority at Cambridge remained opposed to the Liberal government's plans to adopt the ballot.

The committee report was published in March of 1870 and, it was in favour of the enactment of secret voting. The ballot was considered to be an effective remedy against the corrupted practices employed in the elections: 'Much evidence has been given by witnesses not exclusively confined to any political party, to show that the discontinuance of open voting, and the substitution for it of secret voting, or vote by ballot, would be of great advantage in Parliamentary and Municipal Elections'. ${ }^{79}$ The committee report stated that it did not base its arguments merely on the 'theoretical arguments' usually used in relation to secret voting, but rather on empirical evidence. ${ }^{80}$ The colonial experience with the ballot, especially in Australia, was portrayed in positive terms in relation to the reduction of bribery. It seems that, henceforth, the colonial example, now known as the 'Australian ballot', became the focus of the broader debate on secret voting. ${ }^{81}$

But there were still those who found the question of the ballot against their political principles. Harcourt, now in the House of Commons, contested the idea of compulsory secrecy of the ballot in the second reading of the bill, even though its

\footnotetext{
${ }^{77}$ Report from the Select Committee on Parliamentary and Municipal Elections; with the proceedings of the committee, and an appendix, House of Commons, 15 March 1870, p. 2, $<$ http://gateway.proquest.com/openurl?url_ver=Z39.882004\&res_dat=xri:hcpp\&rft_dat=xri:hcpp:rec:1870-046035> [accessed 14 February 2014].

${ }^{78}$ D. Campbell, motion presented in the Cambridge Union, 9 February 1869, Cambridge Union Society Minute Book, vol. 19.

${ }^{79}$ Report from the Select Committee, p. 7.

${ }^{80}$ Report from the Select Committee, p. 8.

${ }^{81}$ Cf. Asquith, 'The Ballot in England', p. 661.
} 
general principles had already been agreed to. Additionally, it seems that Harcourt decided to put his own immediate political interests aside. He was a Liberal MP (186880) and, therefore, on the side of the government. On this occasion, he was acting independently in his opposition to the government bill. From the viewpoint of parliamentary procedure, his opposition was not only inconsistent but also against the rules. $^{82}$ In spite of this, he resumed the discussion about the principle of secret voting and made it clear that the ballot was a matter that he did not endorse: 'It was never an agreeable position for any person to occupy to feel it his duty to support opinions which he entertained when those opinions were at variance with the views of the mass of the party with which he sincerely thought and generally acted'. ${ }^{83}$ Harcourt's resistance had to do with the notion that the ballot would restrict political freedom. This idea derived from the suggested provision to the bill, according to which anyone at a polling station who 'wilfully' showed whom he had voted for could face imprisonment. During the debate, Harcourt was the leading opponent of the provision. He said that he would support the bill as long as it did not stifle the freedom of voters to choose whether they would vote publicly or by secret ballot. He maintained that he 'should always oppose the Ballot when there was mixed up with it any proposal which could prevent people voting as they liked'. ${ }^{84}$ His objection to the provision was based on the idea that it would deprive of voters of the freedom to choose, in the sense that if they opted to vote publicly, for example, by showing their ballot paper to others at the polling station, they might end up serving a prison sentence. In other words, he opposed ballot secrecy if it was made compulsory. ${ }^{85}$

\footnotetext{
${ }^{82}$ Cf. Redlich, Procedure of the House of Commons, p. 229.

${ }^{83}$ Harcourt, speech to the House of Commons, 18 April 1872, Parliamentary Debates, Commons, third series, vol. 210, col. 1485.

${ }^{84}$ Harcourt, speech to the House of Commons, 18 April 1872, Parliamentary Debates, col. 1488.

${ }^{85}$ Harcourt's idea seems to favour consensual decision-making, more recently advocated by Habermas, that rather dismisses the problems associated with conformity of opinion.
} 
The secret voting method was passed into law in 1872 by the Gladstone government, despite the fact that there was no general public support for it at the time. Gladstone himself had been against the secret ballot, but started to advocate for it while aiming to secure his newly attained premiership, as the majority of his Liberal supporters in the House of Commons were in favour of secret voting. ${ }^{86}$ In 1888, Asquith wrote that elections had become more efficient and less corrupt since the secret ballot was adopted. ${ }^{87}$ Even though Harcourt's views seem perhaps irrational from this perspective, they have to be seen in the context of the debating culture and continuous opposition against secret voting since the 1840s. Even such a principled Liberal as John Stuart Mill had come to oppose the ballot because it evoked connotations of 'unEnglishness'. ${ }^{88}$ In Mill’s newly acquired rationale, the secret voting system represented anti-Utilitarian principles and was against freedom of voters. Harcourt's argument against compulsory secrecy derived from the perception that the secret ballot might, ultimately, restrict, rather than guarantee, the political freedom of voters. This take on the question was also seen in MacChymont's motion in the Oxford Union debate above. However, the majority of members of the Oxford Union present in the debate considered the adoption of secret ballot a necessary step to fight against corruption in parliamentary elections. This serves as yet another illustration of the fact that the Unions were involved in the intellectual debates of their time and that there was an overlap of debate agendas between the Unions and the British parliament. But it also shows that the Unions did not simply imitate the debates in the House of Commons, as the majority of Cambridge Union members remained adamantly opposed to the adoption of ballot in parliamentary elections. As Bagehot put it, in this 'age of

\footnotetext{
${ }^{86}$ Kinzer, 'The Un-Englishness of Ballot', p. 253.

${ }^{87}$ Asquith, 'The Ballot in England', p. 672. Both Asquith and Gladstone had served as presidents of the Oxford Union Society. Asquith was elected in 1874 and Gladstone in 1830.

${ }^{88}$ Kinzer, ‘The Un-Englishness of Ballot', p. 237.
} 
discussion', no political topic was predetermined but submitted to consideration of a 'House', to the procedural weighing of its pros and cons.

\section{CONCLUSION}

My main argument here has been that we can learn more on British parliamentary history by extending the analysis of debate and procedure to the nineteenth-century Cambridge and Oxford Union Societies. This approach takes parliamentary culture as its starting point. My aim has been to show that the Union Societies were part of such a culture: they contributed to it and shaped it by actively following and responding to contemporary debates in the House of Commons.

The Cambridge and Oxford Unions were formed in a period when the reform movement had grown stronger and unrest due to the disfranchisement of the larger part of the population had become a constant threat to the constitution. The first Reform Act abolished the nomination system in 1832, but the secret ballot question remained on the political agenda, due to increased electoral corruption, until the 1840s. The Grey government anticipated that, by changing the old system of nomination boroughs, the electoral power of the landowners would be diminished. The result, however, was that the landowners, instead of nominating their candidates for parliamentary seats, opted for using bribes to buy their votes from freehold voters.

Secret voting was a topic that did not have wide popular support in Britain in the 1850 s and the 1860s. The political discourse changed only when some radical Liberals, having become concerned about the effects of the corrupt electoral practices on the independence of voters, were able to put pressure on the Gladstone government. In Physics and Politics (1872) Bagehot described the parliamentary culture between the two Reform Acts in 1832 and 1867 as 'the age of discussion'. The 'government by discussion' was the constitutional form that was realised by the increased role of the 
House of Commons. The cabinet was chosen among its members as 'executive committee' that had to enjoy the confidence of the majority. In this manner the House of Commons was the 'true sovereign' exercising executive power. ${ }^{89}$ Moreover, in Bagehot's view, the British constitution had turned into the form of 'government by discussion' by the change from the 'age of status' to the 'age of choice'. He argued that the 'age of choice' was recognisable in the manner in which legitimacy of political questions was sought by discussion of topics without any attachment to 'fixed customs'.90

Bagehot's idea of debate in the contemporary constitutional setting was connected to notions of freedom and civilisation. The idea of free debate was embedded in the parliamentary culture, which can be seen extended to the Union Societies' debating practices. The Unions were closely following the reform debates in Parliament. Sometimes their debate topics anticipated those presented in the House of Commons, as when, at times, they extended the parliamentary debates into their own 'House'. The members put forward current political issues in Union meetings for the purpose of practising debate, which in the new political landscape of the mid-nineteenth century, stressing party alliances and publicity, had become a crucial skill to master. The expectation in this parliamentary culture, however, was that those taking part in the culture would be able to contribute to the debates independently. Harcourt's opposition to the secret voting bill is a good example of this. He was allowed to put forward an amendment to a government bill in a rather late stage of its passing into law. But his opposition can also be regarded in intellectual terms. Since the 1850s the secret ballot commonly represented the 'un-English' value of concealment. This was a powerful argument also embraced by Mill who argued that the English have an aversion to lying

\footnotetext{
${ }^{89}$ Bagehot, The English Constitution, pp. 98-9.

90 Bagehot, Physics and Politics, 'No. V.: The Age of Discussion'.
} 
and that, for them, the adoption of secret voting is another form of 'disguise' that would mean 'a badge of slavery'. ${ }^{91}$

My analysis of the secret voting discussion from 1830s to 1870 s shows that there were two different views of the role of debate. Although Bagehot did not explicitly discuss open voting and corruption, he attached the notions of independence and freedom to debate with his idea of the 'age of choice'. His characterisation of the period as the 'age of discussion' was also apt in relation to the prevalent electoral practices: the elections had moved from what he termed the 'age of status' to the 'age of choice'. The competition of parliamentary seats had grown significantly after the abolition of nomination boroughs. The open voting system was clearly corrupt, but its proponents were rather sincere in the reasons they stated for supporting it. Mill considered the corruption related to elections as a 'lesser evil'. His opposition to secret voting was based on an idea that a voter who was free of landowner influence was independent and, therefore, more or less equivalent to a parliamentarian who was elected to Parliament through a corrupted system. In other words, according to Mill, corruption was not as important a factor as independence to express public support for a candidate when it came to open voting.

The secret ballot debate shows that there were two very different interpretations of the role of debate. Bagehot's 'age of choice' located debate to the acting out of parliamentary procedure. He maintained that the putting up any topic for discussion was itself an admission that it was not settled, but could be freely discussed without a predetermined political position. In Mill's conception of debate, voters were compared to parliamentarians. In his view, however, it did not matter whether the other

\footnotetext{
91 J. S. Mill, 'Thoughts on Parliamentary Reform (1859)', in The Collected Works of John Stuart Mill, Volume XIX - Essays on Politics and Society Part II, $<$ http://oll.libertyfund.org/?option=com_staticxt\&staticfile=show.php?title\%3D234\&chapter=16563\&lay out=html\&Itemid=27> [accessed 14 February 2014].
} 
views or positions were recognised or not. In open voting, the debates were not about putting forward just any topic or issue in order to discuss it pro et contra, rather, it imposed a situation where a set choice of candidates had already been proposed and thereby framed the debate as being either in opposition or in support of them. Compared to parliamentary speeches, those given in support of electoral candidates are considered secondary in relation to debate. ${ }^{92}$ In other words, platform oratory of public meetings may be aimed at suppressing the need to debate, as it is assumed that the public address itself will provide the necessary elements to engage and persuade the audience.

To sum up, in the parliamentary culture, within which the Unions participated, there existed competing ideas of debate. One of these, shown in Mill's argument against the secret ballot, was connected to extra-parliamentary politics; another, emphasised in Bagehot's 'age of discussion', follows the parliamentary logic. Mill's conception was rather specialised, as it derived from his own argumentation against secret voting. Therefore, Bagehot's definition must be underlined, or how 'the age of choice' related to the entire political culture, which was dominated by parliamentary government at the time. Bagehot's description also better corresponds with the function of the Union Societies, which was formed for the purpose of parliamentary-styled debate, of weighing pros and cons. In terms of political activity, the changed expectations after the 1832 Reform Act affected the way debate came to be seen: that is, more as a required skill, than as a contrived ritual.

Taru Haapala is a Research Fellow in the Centre in Political Thought and Conceptual Change in the Department of Social Sciences and Philosophy at the University of Jyväskylä, Finland. She holds a $\mathrm{PhD}$ in Political Science from the University of Jyväskylä (2012) and her thesis was entitled “"That in the Opinion of this House”: The

\footnotetext{
${ }^{92}$ G. J. Holyoake, Public Speaking and Debate. A Manual for Advocates and Agitators, new edition (Boston, 1897), p. 80.
} 
Parliamentary Culture of Debate in the Nineteenth-Century Cambridge and Oxford Union Societies'. Her research interests include the formation of the Westminster-style debating culture, political rhetoric and history of political thought. In 2013-14 she was awarded a postdoctoral grant with the Kone Foundation to extend her existing research to work on a project entitled 'The Political Uses of Parliamentary Procedure in Nineteenth-Century Debating Societies in Britain'. Her current publications include 'Parliament as a Model for Debating: Procedure Debates in the Cambridge and Oxford Union Societies', in K. Palonen, J. M. Rosales and T. Turkka (eds), The Politics of Dissensus: Parliament in Debate (Santander, 2014), and 'Debating Societies, the Art of Rhetoric, and the British House of Commons: Parliamentary Culture of Debate before and after the 1832 Reform Act', Res Publica: Revista de filosofía política, 27 (2012). 